\title{
The Researching work process-oriented vocational colleges curriculum
}

\author{
e-mail: weilh@ncut.edu.cn
}

\author{
Lingjun Wei \\ Automotive Engineering \\ Beijing Vocational College of ransportation, \\ Beijing, China \\ e-mail: wljyal66@126.com
}

Linghui Wei

Mechanical and Materials Engineering

North China University of Technology, Beijing, China

\author{
Jianjun $\mathrm{Xu}$ \\ Automotive Engineering \\ Jinhua Vocational and Technical College, \\ Zhejiang, China \\ e-mail: 12687271@qq.com
}

\begin{abstract}
The rapid development of national economy, not only requires the occupation education to meet the personnel quantity requirements, but also to ensure the quality of talents. In order to make the occupation education and healthy development, the state issued a series of preferential policies, to encourage students to enter the occupation college, also set aside funds to support the development of a large number of occupation education. As culture occupation occupation colleges talents must do a good job of the personnel training work, provide qualified enough, the occupation personnel for the country's economic construction, combined with China's specific national conditions, explore the work-process-oriented curriculum system is suitable for the development of education in our vocational curriculum system, to our country to cultivate applied talents of technology.
\end{abstract}

Keywords-working process; The curriculum system; Reform in Educatio;Vocational Education;Technical personnel.

\section{INTRODUCTION}

It has become a general talent training goal for the higher vocational colleges to train a large number of high-quality practical talents for the society who have high professional and technical ability, work ability, social ability and creative ability, and it has become the common pursuit of the goal of vocational colleges to draw lessons from international advanced vocational education ideas and teaching methods and innovate modern vocational education ideas and methods. Due to the short time on vigorously develop vocational education in our country, it is no a model of vocational education patterns, also does not have relatively mature vocational education courses system. Therefore, for vocational education in our country, it is facing the opportunity of development, but also a huge challenge. If we did want to do a good job in the vocational education of our country, it is necessary to reform radically to the existing vocational education system, course system, teaching method and means. In the process of reform, we can find a suitable for the situation of our country's vocational education mode by drawing lessons from foreign successful vocational education mode and combining with the specific situation of the vocational

education of our country. The Ability Bring up was specific performanced of Communication Skills, Innovative skills, Working with people, information processing, foreign language, self-improvement, problem solving and math skills eight areas ${ }^{[1]}$. As shown in Tbable 1

TABLE 1. Value judgment of professional competence in the work process

\begin{tabular}{|c|c|c|c|c|c|}
\hline $\begin{array}{c}\text { Significant } \\
\text { added value }\end{array}$ & & & & & $\begin{array}{c}\text { Solve the } \\
\text { problem }\end{array}$ \\
\hline $\begin{array}{c}\text { Improve } \\
\text { team value }\end{array}$ & & & & $\begin{array}{c}\text { Management } \\
\text { level }\end{array}$ & \\
\hline $\begin{array}{c}\text { Significant } \\
\text { value creation }\end{array}$ & & & Teamwork & \\
\hline $\begin{array}{c}\text { Start creating } \\
\text { value }\end{array}$ & & $\begin{array}{c}\text { Work } \\
\text { independently }\end{array}$ & & & \\
\hline Leaming & $\begin{array}{c}\text { Meet } \\
\text { the job }\end{array}$ & & & & \\
\hline Enterning & 6 months & 12months & 18 months & 24months & 30months \\
\hline \multicolumn{5}{|c|}{ Basic elements---Seniority, Knowledge. Skilling and Attitude } \\
\hline
\end{tabular}

\section{THE STATUS QUO OF VOCATIONAL EDUCATION IN CHINA}

Vocational education in our country has developed for decades, but it doesn't been got enough attention in most of the time, including the small investment in manpower, material resources, financial resources, whose development is slow. Our country's vocational education have found some good vocational education models, for example enterprise, the industry also has appeared in running schools, work-study program, but it is not really developed, and has the larger gap between foreign vocational education.

With the continuous development of our economy, the requirement of vocational education is also higher. The quality of the national economic development depends largely on the quality of talents in economic development. Since the reform and opening up, China's economic and technological development have been rapid from all walks of life. In order to adapt to the development, a lot of applied technology talents are needed, especially the auto industry, 
which has been in high development in the last two decades. The car has entered the ordinary people home, from the luxuries to transport, and it has over 5 million cars in Beijing $^{[2]}$, which has entered the car era. With the rapid development of the car, the car after market is also in the corresponding speed developing. At the same time, all kinds of auto service industry is emerging and developing, and the $4 \mathrm{~s}$ shops which are given priority to vehicle maintenance and repair have been all over the country. Auto service industry is also increasing demand for all kinds of talents, especially presenting the blowout demand in recent years, but it is still a common problem to the separation of theory and practice. What's more, there is a larger gap between the practice of vocational education to cultivate talents and the requirements of the industry, the enterprise.

To make vocational education healthy development, the country launched a series of preferential policies to encourage the students to go to the vocational colleges and set aside a large amount of funds to support the development of vocational education. As the vocational colleges and universities that are responsible to train professional talents must do a good job in the talent cultivation, so that it can provide with a sufficient number, quality, qualified professional talents for the country's economic construction.

Look from the world advanced vocational education mode, it is the students' ability training that is regarded as the first goal of vocational education without exception, which pays more attention to students' ability of application knowledge training and the cultivation of the students work method. But most of our traditional vocational education are adopted subject mode, which on the value of the students' ability training is far from enough, and the excellent students need to have a long adjustment period to meet the enterprise needs. Besides, many students think that learned in school are useless completely to the enterprise, and knowing what learned useful was many years later. We wouldn't keep up with the pace of The Times development if we won't reform this out of the vocational education model. Therefore we must carefully absorb foreign advanced vocational education success experience, combining with China's specific national conditions, and explore the mode of development of vocational education to develop China's vocational education curriculum system and to cultivate a large number of applied technology talents in our country.

\section{III.THE ADVANCED EXPERIENCE OF GERMAN VOCATIONAL EDUCATION SYSTEM}

So-called "dual system", that is, vocational colleges and enterprises work together to complete professional ability training for students of a vocational education mode, is a kind of "professional ability" as the standard, "for the future work and learning" as the goal, to "the development of occupational activities" as the core of vocational education model $^{[3]}$. First of all, vocational education institutions will professional ability of a particular type of work required in accordance with the law of distinguished is divided into three basic ability, professional ability, specialty ability of progressive levels, in different levels of professional ability training, according to the modular teaching. Each module of the implementation of the teaching in vocational schools and related enterprises of the basic training place. 's vocational schools for the students to form certain professional quality, have a basic theoretical knowledge and professional skills required to imparting professional theory knowledge, teachers through heuristic, discussion method, group learning advanced teaching method is mainly to solve the "why" of the application of this problem. Enterprise through the analysis of project teaching, task driven and other advanced teaching methods so that the students with "how to do and how to do it will be better". All training activities of the organization is "take the student as the main body," the mentor teachers into occupational activities and counselors, students into the initiative to obtain knowledge and skills, students' learning initiative and enthusiasm has made full play.

Students generally accept practice and professional training in enterprises for 3-4 days in a week, and education of theory for 1-2 days in the vocational school. Vocational school teaching tasks mainly use professional theory to counsel and improve the training results of students in the enterprise practice, and deepen and complement the task of general education. About $60 \%$ are professional courses, $40 \%$ are general education courses. Can be seen from the above model, enterprise skills training is the main part of the "dual system", the vocational school education is to serve the enterprise training ${ }^{[4]}$. The role of the "dual system" is to give students the knowledge and skills needed to engage in trade, is the nature of the ground. No matter which level they are in occupation in the future, the "dual system" vocational education (training) is a necessary condition. "Dual system" is that professional education is managed macroscopically by the government, schools, departments of industry and production units is to organize the implementation of the triple system.

Correspondingly development process of German car professional curriculum system is based on the guiding ideology oriented by working process, cultivate the students' comprehensive ability as a target, fully consider the enterprise's development and its requirement for talents, and to find suitable for students ${ }^{[5]}$.

Used and selection of German vocational education teaching methods is determined based on the goal of vocational education and the teaching content, according to different teaching objectives, according to the actual situation with typical characteristics, the adaptive method of teaching. German vocational education teaching methods is to keep high scientific and objective ${ }^{[6]}$.

\section{IV.WORKING PROCESS ORIENTED CURRICULUM SYSTEM}

Using German dual system of vocational education, combining with our own actual situation to build curriculum system, specifically including the following aspects of content:

\section{A. research and analysis}

Research and analysis is the basic work on the development of vocational education curriculum, is further defined professional Settings, professional orientation, professional connotation, determine the basis of training target and talent specifications; in accordance with the vehicle maintenance enterprise professional post demand and requirements of personnel training, Is to plan and 
determine the needs of the personnel training mode, and is the foundation of the working process oriented curriculum development . Its main goal is: to understand the market demand, a clear professional direction and connotation; Understand post (group) demand and demand of choose and employ persons, clear personnel orientation, personnel specification, provide the basis for this professional course structure.

\section{B. refined typical occupational activities}

Through interviews of enterprise and expert discussion in maintenance, according to the common the content of the work and the work of knowledge of the enterprise, we can determine hose reflect the nature of work area ,typical and occupational activities of education value and the working process of a typical professional activities in the vehicle maintenance enterprise, including car maintenance, mechanical repair auto, fault diagnosis and performance test of four types of typical occupational activities ${ }^{[7]}$.

\section{c.from a typical occupational activities into a typical learning activities}

Typical occupational activities into learning activities, it needs to arrange a typical professional activities from work content, work, work objects, the use of tools, working methods, Labour organization, work requirements and standards, professional standards, etc. conclude as a typical occupational activities analysis table, then analysis table into professional course based on the basis of typical occupational activities ${ }^{[8]}$, Figure1 and Figure 2 below is Case from a Car repair business occupational activities into a typical learning activities.

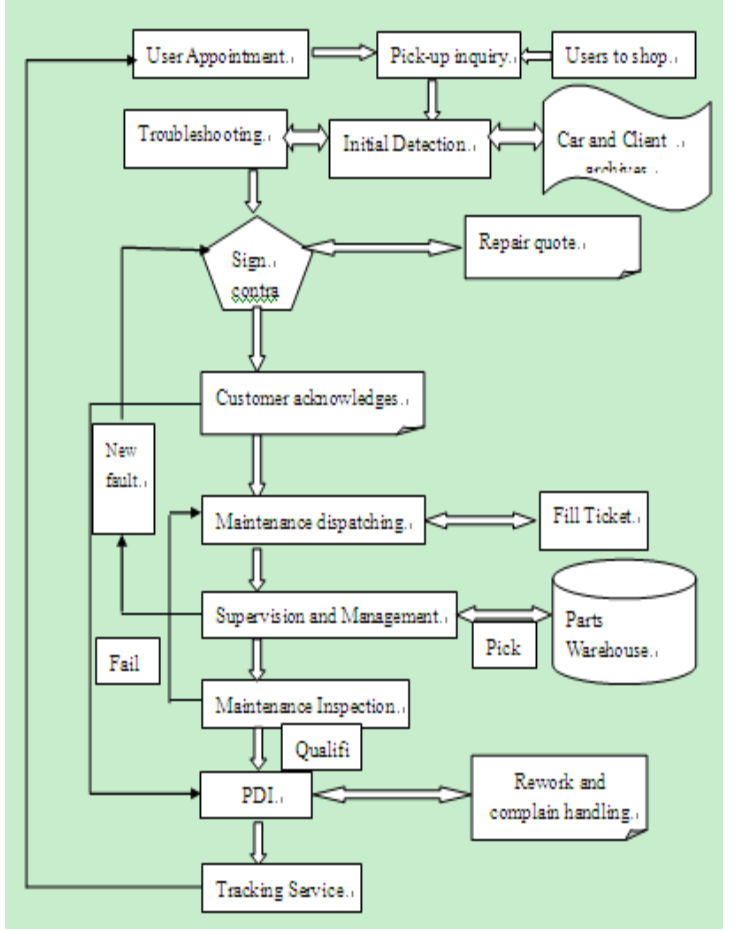

Figure1. Occupational activity flowchart

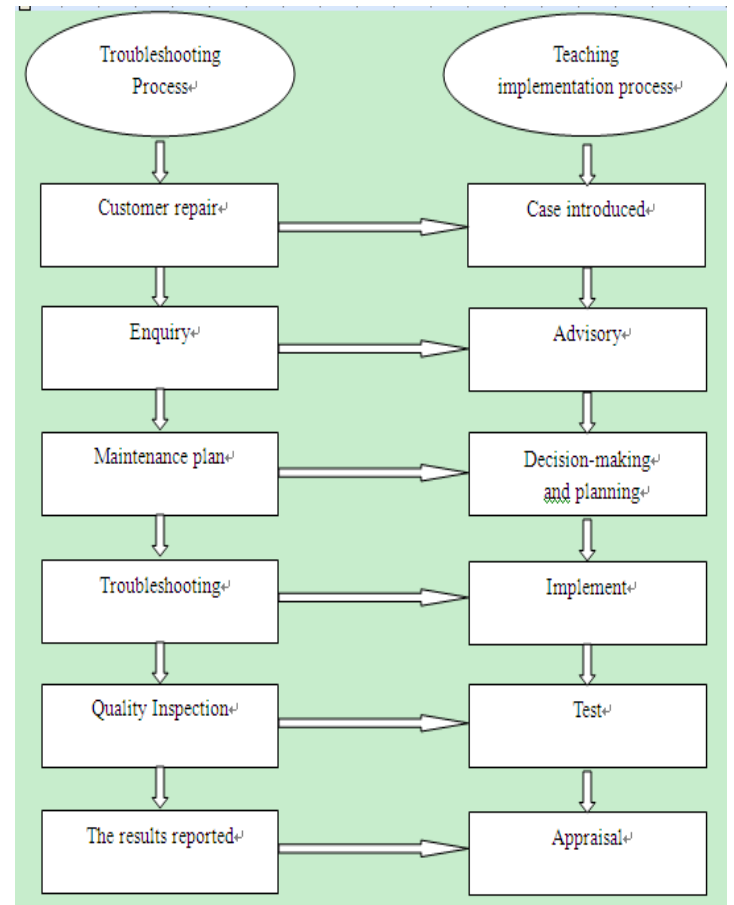

Figure2. activities into a typical learning activities

\section{D.making professional teaching plan}

In accordance with the relevant regulations, the basic content of teaching guidelines include: name of the professional, recruit students object, system, training objectives and specifications, the graduates should have professional ability, of course, the teaching activity time distribution table, curriculum setting and teaching schedule, teaching basic requirements, instructions, etc.

\section{E.establishing specialized core curriculum standard}

Professional core courses is about according to automobile application and service specialty occupational students' employment typical activities directly into courses and complete student employment typical automobile application and service specialty vehicle maintenance and repair in the occupational activities required knowledge and ability to integrate curriculum. Including specialized core curriculum standard content, the curriculum nature and the task, reference class, course credits, curriculum objectives, content, evaluation standard, teaching implementation Suggestions, etc.

The working process of the system to guide the curriculum implementation experience

Through this curriculum reform, we get some of action-oriented curriculum development and the experience of building specific as follows:

1) university-enterprise cooperation is the only way of class changes

2)using advanced vocational education mode

3) strengthen the guidance of the basic education theory

4) improve the level of teachers, strengthen the training of the practice

5)strengthening the construction of teaching resources, improve the level of complete set

In the concrete implementation process, because of the large equipment, teachers and other issues, it does need to 
improve in some aspects, but in the working process of the system into oriented curriculum system in the implementation of the teaching process, according to the situation of the students using a variety of teaching methods, such as brainstorming, role playing method, discussion method, CARDS method and demonstration method, demonstration method, program method, conversation method, etc. The teaching method of integrated application of comprehensive, fully embodies adaptability, educational, practical, interactive and developmental characteristics of the teaching process, in the process of cultivating students it has achieved fruitful results ,for example fully embodying the connotation of the education of knowledge, promoting the development and mobilizing students' learning ${ }^{[9]}$.

In order to realize the training objectives of vocational ability as the standard, through professional activities as the core design patterns, to cultivate effectively students' professional knowledge and professional skills. "Working process oriented" curriculum fully embodies the design idea of occupational activities as the core, to cultivate students' ability to master the effective professional skills and professional purposes ${ }^{[10]}$.

\section{V.SUMMARY}

In short, through the teaching reform, we deepen our understanding of vocational education, for our future teaching work it has played a guiding role. Throughing Carefully studying the characteristics of vocational education in China, actively absorbing and learning from world civilization's good results and according to the actual situation of our college, embarking on a road with our own characteristics of the road to education reform, which accords with the situation of China's vocational education reform.

\section{REFERENCES}

[1] Dayuan Jiang. The theory of German vocational education professional occupational model $[\mathrm{J}]$. Journal of vocational education BBS, 2008 (8).

[2] Binghe Chen. The characteristics and enlightenment of vocational education in Germany [J]. Journal of education and profession, 2006 (14).

[3] Yuanzheng Sun , etc. The special features of German vocational education and reference $[\mathrm{J}]$. Journal of Liaoning normal university, 2005 (3)

[4] Gunter Walden dual vocational education and training in the service society [J]. J BWP. Special edition 2009200 9:24 to 25

[5] Thomas Sondermann The German Vocational training Reform Act of 2005: What is new, What is The company [J]. Journal of BWP. Special edition 2005200 5:18.

[6] Qilong Li. World education system: German education [M]. Changchun: Jilin education press, $2000290 \sim 291$.

[7]Jingyu Li, etc. effective teaching reflection In the teaching [J]. Chinese science and education innovation Tribune, 2010 (2)

[8] Tianxun Chen. Construction and Practice of the working process of systematic curriculum system [J]. Journal of vocational education BBS, 2009 (8).

[9] Zhengyi Li. Based on work process-oriented curriculum developmen [J]. Tianjin Professional College Journal, 2010 (6).

[10] Runguo Huang. Construction and Exploration based vocational curriculum system working process [J]. Journal of vocational education BBS, 2010 (9). 